\title{
高分子膜による無菌化食品の開発
}

原田三郎

\section{Food Development by Sterile Filtration with Polymeric Membrane}

Saburo HARADA

Abstract: Sterile filtration with polymeric membranes is useful to create fresh flavor food that has few changes on color and aroma. Keywords: Membrane/Sterile Filtration

食品の製造では不要物を除くためにろ過をし，調理ある いは濃縮や殺菌をするために加熱が行われる。食品は出来 立てが一番掞いしいと言われ，保存のために加熱濃縮や加 熱殺菌をすると風味が損なわれることがある。膜ろ過を使 用することで，加熱に代わる効果を期待する食品製造関係 者は多い。

最近の膜は耐薬品性や耐熱性が向上している。専用の膜 洗剂の開発む進んでおり, 食品への膜利用の環境は良く なっている。しかし, 食品は多成分で高濃度のものが多い のでファウリング（膜自体の構造は変化せずに目詰まりや 付着層の形成によって膜の機能が低下寸る現象）が問題上 なるので，これを抑える操作方法などソフト面の開発も重 要である。それでも, 食品は種類が多く成分が微妙に異な り, 風味之いう感性で決められる部分があるので, 膜の選 定など一品一様の設計が必要となることが多い。

食品の清澄化では珪藻土をろ過助剤としてろ過すること が多かったが, 万過残渣の廃棄が問題となり, 奨油や食酢 など䤑造食品を中心として珪藻土を使用しない方向での技 術開発が進められてきた。代替技術として膜導入が図ら れ, 品質の改善にもなった。理藻土ろ過した槒油では生菌 が $10^{2}$ から $10^{4}$ 個 $/ \mathrm{mL}$ 程度検出されていたが， $0.2 \mu \mathrm{m} の$ MF 膜 (精密万過膜) でろ過した酱油はほぼ無菌となる1)。 清酒への膜利用では, 菌体だけでなく貯蔵中の劣化原因と

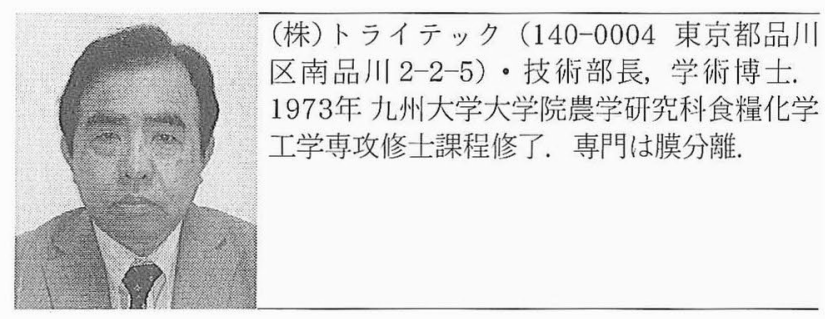

\begin{tabular}{|c|c|c|}
\hline 無菌化乃過食品 & 膜種 & 万過対象 \\
\hline 眢油 & $\mathrm{UF}, \mathrm{MF}$ & 酵母, 細菌除去 \\
\hline めんつゆ & $\mathrm{MF}$ & 細菌除去 \\
\hline 生酒 & UF & 酵母と酵素の除去 \\
\hline 生果汁子ュウーハイ & UF, MF & 果汁の細菌除去 \\
\hline ハチミッ & UF & ボッリヌス菌胞子の除去 \\
\hline 野菜汁 & $\mathrm{MF}$ & 生姜など, 細菌除去 \\
\hline 食酢 & $\mathrm{UF}, \mathrm{MF}$ & 酢酸菌, 細菌除去 \\
\hline ミネラルウォーター & $\mathrm{UF}, \mathrm{MF}$ & 細菌除去 \\
\hline
\end{tabular}

なる酵素の除去を兼ねて, UF 膜 (限外万過膜) での処理が 検討された結果, 生酒という新しい製品が開発されてい る。菌を集めて利用する場合あある。乳酸菌は MF 膜で活 性が高い状態のまま高濃度に濃縮し, 乾燥などの炕理をし て健康食品として商品化されている。高分子膜での無菌化 ろ過が行われている食品を表 1 に示した。無菌化ろ過が殺 菌に代わる技術として本格的に使用されたのはミネラル ウォーターである。従来は $85^{\circ} \mathrm{C} て ゙$ 加熱殺菌して耐熱容器 へ充填されていたが，無菌化ろ過とすることで常温充填が 可能となり, ブロー成型した容器が使用できるようになっ た。これは容器コストの大幅な節減につながっている。こ れ以降, ミネラルウォーター生産量は順調に伸びている。

食品の菌を不活性化する方法として, 膜ろ過は加熱殺菌 々同等の効果があり, 耐熱菌に対しては食品のフレーバー を損なわずに衛生面での安全性を高めるという点では加熱 殺菌以上の効果がある。今後, 膜の用途として注目される あのである。

\section{文 献}

1) 松下幸之助 ほ加：日本食品科学工学会誌，49, 611 (2002)

2）全国清涼飲料工業会：ソフトドリンク統計, http://www. j-sda.or.jp/toukei/hinmoku/hin_sui.htm (2008) 